\title{
Characterization of the Brazilian vegetable brassicas production chain
}

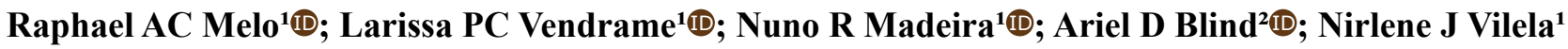

${ }^{1}$ Embrapa Hortaliças, Brasília-DF, Brasil; raphael.melo@embrapa.br; ${ }^{2}$ Instituto Nacional de Pesquisas da Amazônia (INPA), Manaus-AM, Brasil; ariel.blind@inpa.gov.br

\begin{abstract}
Brassica crops worldwide provide the greatest diversity of products used by man derived from a single genus. Collectively, leafy, flower and root vegetables can be eaten fresh, cooked and processed. The production of these vegetables in Brazil has been growing exponentially in the last decades, due to its economic importance, with major production volumes in several states and a quick monetary return for growers in areas considered of small acreage. With expansion, a number of aspects, including demands for quality and safety of these foods introduce themselves, strictly attached to the forms of production, logistics and their appearance. To meet the challenges and list the trends within the activities of different agents, a multiple case study was held in the states of Amazon, Minas Gerais, Paraná and Rio de Janeiro. Altogether, 55 stakeholders were interviewed, along with the compilation of different sources of data to characterize this productive chain. Changes in the scenario are imperative in order to maintain the activity of overcoming years, being related to cultivars adaptation, plant health, productions costs and difficulties during the establishment of crops. To overcome these adversities, a collective effort in terms of organization, technology transfer and R\&D from official and private agents, technical assistance, and regional sanitary inspection is imperative, aiming, especially, in actions regarding themes like protected cultivation, mechanization/automation and adding value to products by processing and packaging, listed by stakeholders as priority.
\end{abstract}

Keywords: Brassica oleracea, diagnosis, scenario, regions.

\section{RESUMO}

Caracterização da cadeia produtiva de brássicas no Brasil

As brássicas em todo o mundo fornecem a maior diversidade de produtos usados pelo homem derivados de um único gênero. Coletivamente, hortaliças folhosas, de flores e raízes podem ser consumidas frescas, cozidas e processadas. A produção dessas hortaliças no Brasil vem crescendo exponencialmente nas últimas décadas, devido à sua importância econômica, com volumes significativos de produção em diferentes estados e um rápido retorno monetário para os produtores, em áreas consideradas pequenas em extensão. Com a expansão, uma série de aspectos, incluindo demandas por qualidade e segurança desses alimentos se apresenta, estando estritamente ligados às formas de produção, logística e aparência. Para enfrentar os desafios e listar as tendências nas atividades de diferentes agentes, foi realizado um estudo de caso múltiplo nos estados da Amazônia, Minas Gerais, Paraná e Rio de Janeiro. Ao todo, foram entrevistados 55 agentes, juntamente com a compilação de diferentes fontes de dados para caracterizar essa cadeia produtiva. Mudanças no cenário são imperativas para manter a atividade, sendo relacionados à adaptação de cultivares, sanidade vegetal, custos de produção e a dificuldades durante o estabelecimento das culturas. Para superar essas adversidades, é imprescindível um esforço coletivo em termos de organização, transferência de tecnologia e P\&D de agentes oficiais e privados de assistência técnica e inspeção sanitária regional, visando principalmente ações em temas como cultivo protegido, mecanização/ automação e agregação de valor aos produtos por processamento e embalagem, como prioritários.

Palavras-chave: Brassica oleracea, diagnóstico, cenário, regiões.

Received on June 6, 2019; accepted on October 2, 2019

$\mathrm{T}$ he study of evolutionary relationships between groups of organisms differs in the number of genera and species that make up the family Brassicaceae, also called Cruciferae (Almeida, 2006; Pires, 2014). Depending on the method, the composition of this family varies between 300 and 400 genera and 3000 and 4000 species. It is included in the order Brassicales when methods that classify groups hierarchically are used. In another approach, the order Capparales and the paraphyletic family
Capparaceae are considered to be part of the brassicas, which includes the caper (Capparis spinosa) (Almeida, 2006).

New ways of use, consumption and derived products or technologies makes the species of this family increasingly present in our daily lives. As an example, the small Arabidopsis thaliana plant is today one of the main tools of molecular biology (The Arabidopsis Genome Iniative, 2000), just as Fast Plants ${ }^{\circledR}$ are becoming important educational and research tools (Fast Plants, 2019), in addition to vegetables that play an important role due to the high concentration of phytochemicals that show several epidemiological benefits, preventing the human body against reactive oxygen species damages and decelerated the progress of many chronic diseases (Idrees et al., 2019).

Brassica crops worldwide provide the greatest diversity of products used by man derived from a single genus. Other members of the family Brassicaceae extend this diversity (Dixon, 2006). Collectively, brassicas deliver leafy, flower and root vegetables that are 
eaten fresh, cooked and processed; used as fodder and forage, contributing especially overwintering supplies for meat and milk producing domesticated animals (Dixon, 2006); sources of protein and oil used in low fat edible products, for illumination and industrial lubricants; condiments such as mustard, herbs and other flavorings; and soil conditioners as green manure and composting crops (Dixon, 2006).

\section{VEGETABLE BRASSICAS PRODUCTIVE CHAIN IN BRAZIL}

\section{Species and consumption}

Amongst the leafy, flower and root vegetables grown nationally, cabbage, broccoli, cauliflower, and collards (Figure 1) are the most known and consumed (Souza, 1983; Filgueira, 2008; IBGE, 2009; Melo et al., 2017; Paixão..., 2017). Arugula or rocket, wall rocket, radish, horseradish, watercress, leaf mustard, turnip, chingensai or pakchoi and brussels sprouts represent a minor cultivated area (Filgueira, 2008).

The Brazilian Consumer Expenditure (POF) is an official government survey which characterizes the structures of consumption, expenditures, income and part of the asset variation of the households, which took place in the years 2008-2009 (IBGE, 2009). A low purchase by the population of fruits and vegetables is observed not only for consumption outside the home, but also in meals at the home. The household availability of such types of food corresponds to only $2.8 \%$ of the total calories, which is considered as insufficient, when taking into account the recommendation for the consumption of 9 to $12 \%$ ( $400 \mathrm{~g} /$ day) of total calories for a diet of 2,000 kcal per day (Bezerra et al., 2017). However, for brassicas, the POF data brings a decrease of $10 \%$ in the consumption of cauliflower, but an increase of $31 \%$ in the consumption of cabbage, $37 \%$ for broccoli and $156 \%$ for collards at the time (IBGE, 2009).

Although not updated, the POF data can partially be explained by the larger volume of cabbage available in the market throughout the year, which influences its acquisition; the prices in cauliflower; also by family income levels, whose consumption is considered regular only in families with higher wages, such as broccoli; and finally for the recent divulgation on the media of attributes like 'detox' in collards/kale.

Still, in another reality, the interest (or need) on food that is easy-to-prepare or ready to consume, especially outside home, has made the food service develop fast in the country. One example is the market of contract foodservice, which represents a total of 13 million meals a day, with a figure of 19.3 billion reals (R\$) per year, offering 210 million direct jobs, with a daily consumed volume of 7.5 million tons of food in 2018 (ABERC, 2019). In Brazil this market is mostly focused on collective meals for company employees and in gaining prominence during the last few years.

Regarding vegetable brassicas in this perspective of food consumption outside home and collective meals, the importance of frozen florets of broccoli and cauliflower is notable, along with other species that are minimally processed or sanitized, indicating that the growth potential of this market is promising. As a case in and volume fluctuations (seasonality) metropolitan or industrial regions, is

point, the national market of broccoli currently moves about $\mathrm{R} \$ 1.2$ billion in retail only, according to data from the Brazilian Seed and Seedling Trade Association (ABCSEM, 2014). The excellent acceptance of the vegetable can be seen in the increase of its offer in supermarkets (fresh, frozen or minimally processed) and in restaurant menus in general. It is a food that meets the needs of the modern lifestyle, which combines practicality in consumption, taste and health, with a per capita consumption estimated of $1.04 \mathrm{~kg}$ per year (Paixão..., 2017).

\section{Regions}

The production chain of these vegetables has been growing exponentially in the last decades, due to its economic importance, with major production volumes in several states and a quick monetary return for growers in areas considered of small acreage (Melo et al., 2017). At present, it represents a strategic activity for the economy of some regions such as the southern border of Minas Gerais state; the 'green belt' of São Paulo city; the metropolitan region of Curitiba, capital of Paraná state and other locations, with growth prospects in different environments. This sector also has a great social impact, generating direct and indirect jobs, from planting to industrialization, whether by the production of fresh,

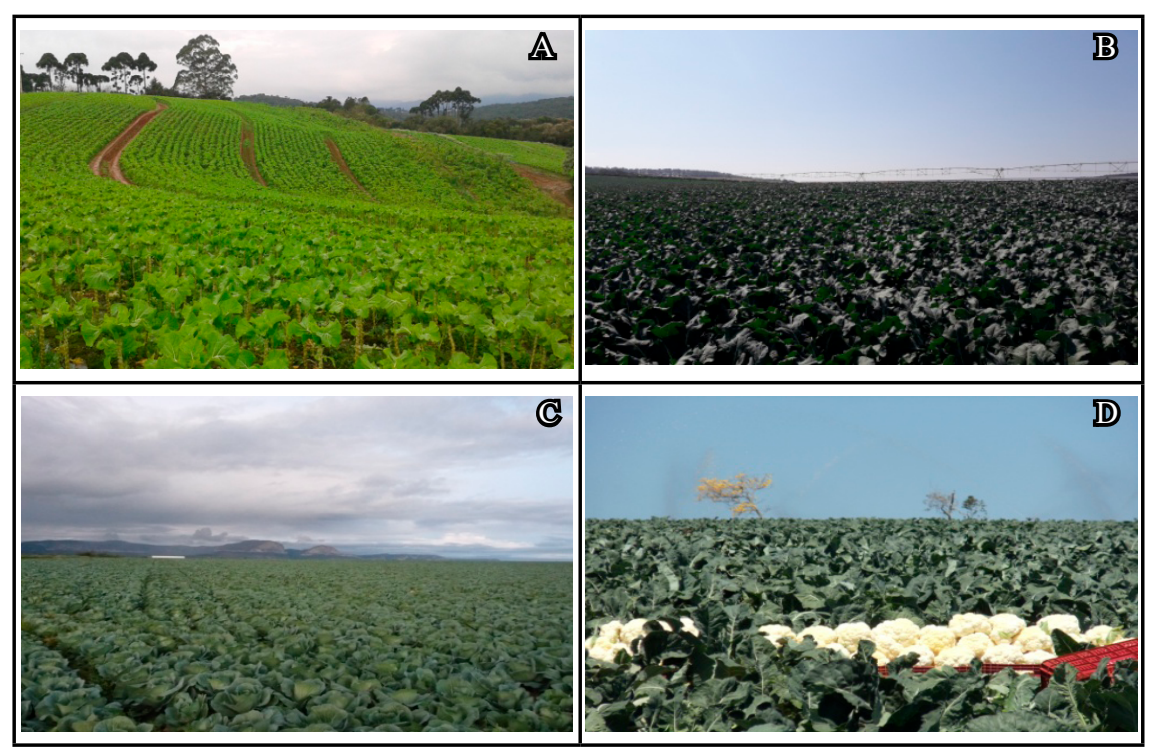

Figure 1. Collards (A), broccoli (B), cabbage (C) and cauliflower (D) grown in different areas of Brazil. Photos by Raphael Augusto de C e Melo; Alice Maria Quezado-Duval. Brasília, Embrapa Hortaliças, 2019. 
minimally processed/sanitized or frozen products (Melo et al., 2017).

An illustration of a paradigm break within the conjuncture of brassicas, being plants of temperate climate origin, is the production in the Amazonian Biome. The state of Amazonas and its capital Manaus are a scenario of intense migration, attracting investors and residents from around the world, who carry with them requirements, customs and food preferences (INPA, 2014). Sprouting broccoli is grown for meet this contingent of migrants and part of the capital population demands, in the municipality of Presidente Figueiredo, using a very simple greenhouse/shelter structure (INPA, 2014).

Harvested area and production volumes

The total national harvested acreage and production volumes projected in the last decade for broccoli by Brunelli et al. (2011) and ABCSEM (2009) extent its area above 15.000 ha. Regarding the production volume, almost 290 thousand tons per year were estimated by Sakata Seeds (Paixão..., 2017). For cauliflower, these projections are above 11.000 ha and 329 thousand tons (ABCSEM, 2009; Brunelli et al., 2011; IBGE, 2006, Melo et al., 2017, CNA, 2017). For cabbage, these numbers are placed above 35,000 ha and 378 thousand tons (ABCSEM, 2009; Brunelli et al., 2011; IBGE, 2006, Melo et al., 2017).

About the current harvested area and production volumes of broccoli, cauliflower and cabbage, with São Paulo, Minas Gerais and Paraná representing the three main states, the 2017 and
2018 seasons data are presented as demonstrative of the aforementioned conjuncture (Table 1).

For Minas Gerais, in 2018, the municipalities of Munhoz with 2.100 ha, Senador Amaral with 430 ha, Lagoa Dourada with 300 ha, Carandaí and Toledo with 250 ha each, all located near the southern border, embody the main region of broccoli production of this state (EMATER-MG, 2019). Carandaí with 600 ha, Toledo and Rio Manso with 250 ha each, Itatiaiuçu with 220 ha and Barbacena with 110 ha represent the cauliflower production (EMATER-MG, 2019). For cabbage, Rio Paranaíba with 405 ha, Carandaí with 300 ha, Lagoa Dourada with 190 ha and Barbacena with 130 ha are the leading regions (EMATER-MG, 2019).

In São Paulo, during the year 2018, broccoli was grown mainly in Mogi das Cruzes with 840 ha, Bragança Paulista with 591 ha and Itapeva with 160 ha (IEA-SP, 2019). For cauliflower, Sorocaba with 771 ha, Bragança Paulista with 602 ha, Itapeva with 520 ha, Mogi das Cruzes with 435 ha and Campinas with 242 ha lead the state production (IEA-SP, 2019). About cabbage, Sorocaba with 5.092 ha, Mogi das Cruzes with 899 ha, Itapeva with 670 ha and São João da Boa Vista with 426 ha represent the key production areas.

Paraná state in the same year, 2018, grew these brassicas mainly in the 'regional' area of Curitiba (SEAB/DERAL-PR, 2019). This area concentrates the municipalities of Araucária, Almirante Tamandaré,
Colombo, Contenda, Mandirituba, São José dos Pinhais and Tamarana as the main ones for the production broccoli, cabbage and cauliflower.

\section{INPUTS - CULTIVARS, FERTILIZERS AND PESTICIDES}

The inputs sector within this production chain is a central component and is intrinsically linked to the productivity of these crops. The main inputs used (seeds, fertilizers and pesticides) are discussed separately.

\section{Cultivars}

The main market for vegetable seed companies is in the brassica production that occurs during winter and mild seasons. The aforementioned production regions are located essentially in the subtropical portion of Brazil. From the central west part of the country to the northeast or north regions, the production is limited to high altitude locations. Only a small part of the brassica cultivars registered at the Ministry of Agriculture, Livestock and Food Supply (MAPA) is in the commercial portfolios that are offered to growers nationwide. Most seeds are imported from other countries and do not adapt to the cultivation under tropical conditions (Melo et al., 2017). Unlike, for example, solanaceous crops, whose seeds portfolios are renewed practically every year, the vegetable brassicas seed market have hybrids that are being sold for over a decade,

Table 1. Harvested area and volumes of the three main productive states of Brazil: broccoli, cabbage, and cauliflower. Brasília, Embrapa Hortaliças, 2019.

\begin{tabular}{|c|c|c|c|c|c|c|}
\hline \multirow{2}{*}{ Harvested area (ha) } & \multicolumn{2}{|c|}{ Broccoli } & \multicolumn{2}{|c|}{ Cabbage } & \multicolumn{2}{|c|}{ Cauliflower } \\
\hline & 2017 & 2018 & 2017 & 2018 & 2017 & 2018 \\
\hline Minas Gerais & * & 4,416 & * & 2,243 & * & 2,146 \\
\hline São Paulo & 2,619 & 2,622 & 9,021 & 7,611 & 2,827 & 2,919 \\
\hline Paraná & 2,642 & $*$ & 8,874 & $*$ & 2,545 & $*$ \\
\hline Production volume (t) & \multicolumn{2}{|c|}{ Broccoli } & \multicolumn{2}{|c|}{ Cabbage } & \multicolumn{2}{|c|}{ Cauliflower } \\
\hline Minas Gerais & * & 69,877 & $*$ & 93,825 & $*$ & 55,266 \\
\hline São Paulo & 42,029 & 46,028 & 321,589 & 305,315 & 58,472 & 70,790 \\
\hline Paraná & 61,985 & $*$ & 333,857 & $*$ & 64,005 & $*$ \\
\hline
\end{tabular}

*Not available. Sources: EMATER-MG (2019); IEA-SP (2019); SEAB/DERAL-PR (2019). 
because of their ability to adapt to distinct environments, but these often don't provide all the necessities of the growers, especially during the warm and rainy seasons. Consequently, the availability of cultivars adapted to Brazilian cultivation conditions is limited and the market encounters challenges in the different segments of the production chain. Seasonal variations of volume and prices are markedly perceived, especially for the broccoli and cauliflower supply, substantiating the need to incorporate in new cultivars multiple resistances and the ability to withstand temperature fluctuations (Brunelli et al., 2011; Silva et al., 2014; Seabra Júnior et al., 2014; Melo et al., 2017).

\section{Fertilizers}

The dependence of certain species to high dosages of fertilizers, their increasing costs and finite reserves of potash and phosphorus, plus the concern about the impact caused by excessive use of these nutrients are factors that require constant improvement in the management of brassicas fertilization (Silva, 2012, 2013; Mendes, 2016; Melo et al., 2017). Moreover, there is a need to update the regional fertilizer recommendations, due to the elevated content of these elements in the soil, either by overuse or by the achieved fertility status over years of cultivation, and especially in the case of some species, by the adoption of new hybrids notably the earlier ones (Melo et al., 2017).

\section{Pesticides}

Due to the significant economic importance, both regarding its toxicity and the scale of its application in
Brazil, pesticides have a wide legal coverage and an extensive number of federal regulations for their registration and use. From 2013 to 2015, the Pesticide Residues Analysis Program (PARA) of ANVISA (Brazilian Health Regulatory Agency) analyzed various vegetables and fruits and obtained several nonconformities. Concerning brassicas, collards and cabbage were the chosen species. A total of 491 cabbage samples were analyzed. Of these, 412 samples were considered satisfactory, 346 did not present residues of the pesticides and 66 samples presented residues in concentrations equal to or lower than the national maximum residues levels (MRL). In total, 19 different pesticides were detected among the 162 pesticides surveyed. Acephate (73 samples), metamidophos (46 samples) and procymidone (44 samples) presented the highest number of detections in the analyzed samples (ANVISA, 2016). A total of 228 collard samples were analyzed. Of these, 150 samples were considered satisfactory, 127 showed no residues of the pesticides and 23 samples presented residues at concentrations equal to or lower than the MRL. In total, 35 different pesticides were detected among the surveyed. Deltamethrin (20 samples), Imidacloprid (17 samples) and LambdaCyhalothrin (14 samples) presented the highest number of detections in the analyzed samples (ANVISA, 2016). To help this situation, approximately 1250 MRLs have been established, benefiting 90 crops and $67 \%$ of the established MRLs belong to Toxicological Class III, i.e, moderately toxic (BRASIL, 2017). As well, 38 trademarks were registered for all minor crops (BRASIL, 2017).

Table 2. Scale of the cultivated area in hectares, species and the economic relevance of brassicas grown in Brazil. Brasília, Embrapa Hortaliças, 2019.

\begin{tabular}{lccc}
\hline Scale & $\begin{array}{c}\text { Cultivated area } \\
\text { (ha) }\end{array}$ & Species & $\begin{array}{c}\text { Order of economic } \\
\text { relevance }\end{array}$ \\
\hline Small & $\leq 3$ & $\begin{array}{c}\text { Several } \\
\text { 1 }\end{array}$ & Secondary $^{1}$ \\
Medium & $\approx 30$ & $\begin{array}{c}\text { Broccoli, cabbage } \\
\text { and cauliflower } \\
\text { Cabbage }\end{array}$ & Main \\
Large & $\geq 80$ & Secondary $^{2}$ \\
\hline
\end{tabular}

${ }^{1}$ Complementary to various agricultural activities (olericulture, grains, livestock, others); ${ }^{2}$ Main activity lies in the production of potato (Solanum tuberosum). Source: Melo et al. (2017).
The inclusion of these products gives the grower more choices of control, in addition to the possibility of rotating modes of action.

Even if the inclusion of these pesticides is beneficial to the cultivation of brassicas, caution in assessing their effectiveness and monitoring the consequences of their use should be a constant measure so that not incur in the possibility of evolution of resistance, notably for diamondback moth (Plutella xylostella) and clubroot (Plasmodiophora brassicae), and also to avoid future problems with nonconformities, whether by government programs or the ones established by retailers (Melo et al., 2017).

\section{OUTLINE OF FARMS, TRANSPORTATION MODAL AND VALUE ADDING STRATEGIES}

The sector presents a very heterogeneous outline when it comes to the production scale of the farms, as their level of adoption of technologies (Table 2). It ranges from large corporate agroindustries to small family owned establishments with subsistenceoriented production and eventual commercialization of surpluses (Melo et al., 2017). Technology adoption is not directly correlated with scale (size), with small areas adopting a high technological level, as well as large extension lands with 'traditional' productive systems. In general, the production of brassicas in a small property divides the space with a great diversity of other vegetable crops (olericulture) that are established in the same area or period, in order to enable the economic activities of the grower (Melo et al., 2017).

In the medium-sized production areas, there is a restriction on the number of species. The botanical varieties of Brassica oleracea (broccoli, cauliflower and cabbage) are the representatives of this scale. Exceptionally, in some regions, Chinese cabbage (commonly denominated in Portuguese as 'acelga' term which refers to the species Beta 
vulgaris var. cicla) makes a small part of these areas, to meet the market demand. In particular, in large areas ( $\geq 80 \mathrm{ha}$ ), priority is given to cabbage cultivation with the intensive use of inputs and irrigation by central pivot. Sporadically, cauliflower and broccoli are grown on this scale, destined to be frozen (florets).

The logistics of the transport and distribution process of brassicas varies greatly between production regions and growers. Some agroindustries use automation for the traceability of their production. But commonly, in the different productive regions, the experience gained by farmers defines the size of the grown area and quantity of production, along with the transport to be used. In this case, the transportation is centered on the grower and intermediaries, who bear all the costs (Melo et al., 2017).

Regardless of scale, the predominant transport modal is the employment of tractors trailers, utility vehicles and trucks. Cold chain (refrigerated transportation and storage) in this modal remains a distant reality, since there are no greater incentives, appropriate legislation or support for related technologies. Most harvested products are stored in inadequate conditions, being often exposed to inclement weather (sun, rain, and wind). Packaging, depending on destination and product, is made stacked, without containers (heaps), in raffia sacks (used mainly for cabbage), plastic boxes and wood boxes (Figure 2) with the latter known to cause mechanical damages and accumulation of pathogens (Lana, 2010; Melo et al., 2017).

Initiatives for value addition of vegetable brassicas are still incipient. Products are commonly sold in natura or in cold display counters. Some growers add value by packing products in plastic films with polystyrene trays (Figure 2A). For leaf species such as watercress, mustard and arugula, square or conical plastic packs are used, some with modified atmosphere. The presentation of products using marketing strategies and novel technologies represents an opportunity, since there is demand from consumers who are willing to pay a differentiated price, counting on the characteristics and facilities of usage. Trademarks, indications of origin and slogans can also be employed by this productive sector, with agroindustries as an exception in the use of these strategies (ITAL..., 2010; Sabio et al., 2013; Melo et al., 2017).

\section{INDUSTRIAL PROCESSING AND FREEZING}

Brazil has great potential for the expansion of frozen vegetables, as they require less storage time and space, and provide labor savings in the preparation and standardization of the size and quality of products offered (Ramos et al., 2013). This market represents an increase in the relative participation in retail offerings, gradually earning more space on supermarket shelves. Broccoli and cauliflower are the favorite frozen brassicas in the market for their availability/demand or little change in its organoleptic properties after the blanching process. The production occurs in an integrated way to the industry, primarily in the Southeast and South regions of Brazil, where the players of this segment are established (Melo et al., 2017).

Industries foster cultivation by supplying inputs to growers and with the guarantee acquisition of production, besides providing technical assistance. Some rent areas for own production in regions near the industrial park to facilitate logistics. Vegetable brassicas in these regions were consolidated in just under a decade, being an alternative to high cost and risky vegetables such as potato, in the off-season tobacco cultivation and in addition to other agricultural activities (Melo et al., 2017). This change made it possible to occupy areas in winter, exclusive to or in parallel with other activities, as well as a decrease in production costs, because brassica species have a small amount of diseases/pests compared to other crops. In this way, the farmers have benefited from regular income and profitability. The configuration of these industries is based on proximity to production regions as well as input suppliers and by the commercialization to different segments, i.e. industrial kitchens and retail market (Melo et al., 2017).

Transactions between growers and industry constantly seek to reduce costs and increase profitability. On the one hand, industries buy in quantity, but aim to negotiate lower values of the products, and on the other farmers deliver the products at the time most favorable to their schedule of cultivation, culminating in a narrow margin of profit (Ribeiro \& Mezzomo, 2004; Melo et al., 2017). This has made part of the productive regions to migrate to sale exclusively to large
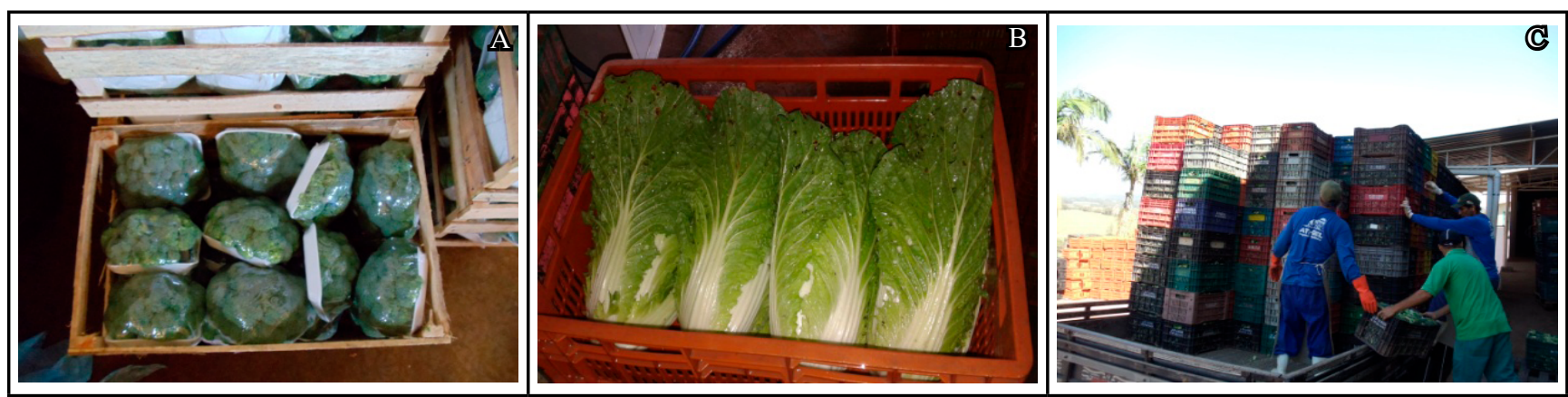

Figure 2. Broccoli (A) and Chinese cabbage (B) stored in wood and plastic boxes (C) transportation in a truck trailer. Brasília, Embrapa Hortaliças, 2019. 
wholesale markets (Ceagesp or Ceasa) due to the possibility of greater gains, and some maintain the production for these two segments in parallel. The combination of these scenarios results in the use of the processing plants fall short of their capacity in certain periods of the year, especially in summer, and the presence of imported products from Europe in the supermarkets (Melo et al., 2017). All these aspects point to the importance and the complex relationship between the pattern of dependence, technological opportunities, making the complementarities and specificity of assets a key tool in the competitiveness of freezing industries and in defining their organizations arrangements (Ribeiro \& Mezzomo, 2004).

\section{CHALLENGES AND TRENDS}

To meet the challenges of this productive chain and list the trends within the activities of each agent (growers, industry, retail market buyer, technical assistant and others), Melo et al. (2017) utilized the multiple case study methodology (Yin, 2010) to characterize different aspects in the states of Amazon, Minas Gerais, Paraná and Rio de Janeiro. Altogether, 55 stakeholders were interviewed in the selected regions. Their answers were related to challenges of cultivars adaptation, plant health, productions costs and difficulties during the establishment of crops. To them, the adoption of mechanization/automation (40\%), protected cultivation (40\%), in addition to adding value to products with processing and packaging (20\%) (Figure
3) are the ways to maintain themselves in the activity of overcoming years.

\section{REMARKS}

On the topic of the use of mechanization/automation and protected cultivation representing $80 \%$, mentions of ambience aspects and ergonomics through the use of equipment and production systems like hydroponics were the major reasons listed. The average age of the stakeholders (40 years and 5 months) and the time they work in vegetable growing activity (14 years) are some of the factors related to this trend, but also the maintenance and continuity within the activity and its stage of development, when there is investment/growth or the intention/ outlook, are the necessities to improve their business. Outline more information about this group, in addition to their age and years in the activity data mentioned, are still necessary for anchoring the trends presented and to obtain other insights.

As regards processing and packaging, the perceptions were about product quality and the need for improvements, either by market demand or by own initiative. Because it is a universe of profiles quite heterogeneous, given the regional or peculiar characteristics of the segment to which they belong in the chain, it is urgent that a regionalized survey within the different niches seeking more information on selection and classification standards, or technologies to be used in this area.

The expansion of production carries a number of aspects, including demands for quality and safety (sanitary, biological and physical) of these foods, strictly attached to the forms of production and logistics. In this conjunction, some growers face problems of maintaining a position within the production chain, with competitive costs, providing the volume and quality required by industries and new channels of retail. These difficulties are inherent in production systems, which need improvements in the availability of cultivars (seeds), mainly adapted to conditions of rainy and high temperature periods; the absence of pesticides registered for target pests and brassica species; and updated usage recommendations of fertilizers either by overuse or by changing the status of soil fertility over the years of cultivation.

Independent of regions and their soil and climatic conditions, nearly the same cultivars are adopted, with reports of disease resistance and physiological problems arising. This demonstrates the lack in some segments and the marketing bias of hybrid availability often not adapted. About diseases, they are closely linked to management and changes in climate parameters that will favor their occurrence and the lack of products registered for its control. Training and awareness actions, especially so that there is no contamination of products and soil, in order not lead to resistance to pesticides are required.

\section{FINAL CONSIDERATIONS}

Different transformations can occur at various levels of this chain and, in this context, the compilation of different sources of data and case studies has enabled to capture changes and gain
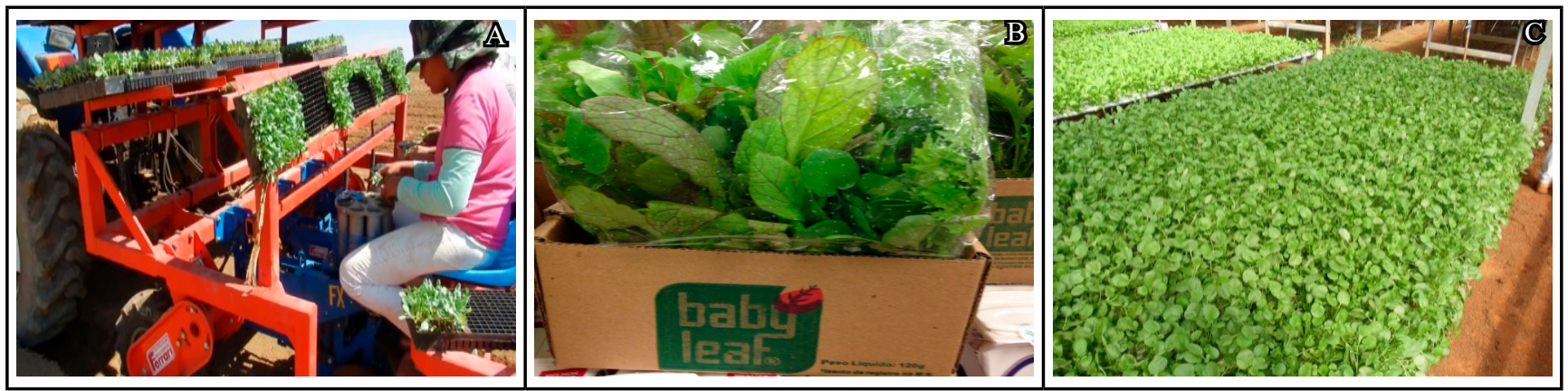

Figure 3. Mechanization (A), packaging (B) and protected cultivation (C) as a response to some of the challenges or constraints faced by growers and other agents of the production chain. Photos: Raphael Augusto de Castro e Melo. Brasília, Embrapa Hortaliças, 2019. 
insights into different segments. Changes in the present scenario are imperative. All the factors mentioned as being essential to brassica growers sustainability on the overcoming years require a collective/ multidisciplinary effort in terms of organization, technology transfer and $R \& D$ actions from official and private agents, technical assistance, and regional sanitary inspection, aiming, especially, themes like protected cultivation, mechanization/automation and adding value to products with processing and packaging, listed by stakeholders as priority.

\section{REFERENCES}

ABCSEM. 2014. Apresentação completa dos dados da cadeia produtiva de hortaliças. Available at $<$ http://www.abcsem.com.br/imagens noticias/Apresenta $\% \mathrm{C} 3 \% \mathrm{~A} 7 \% \mathrm{C} 3 \% \mathrm{~A} 30 \% 20$ completa $\% 20$ dos $\% 20$ dados $\% 20$ da $\% 20$ cadeia $\% 20$ produtiva $\% 20$ de $\% 20$ hortali\%C3\%A7as\%20-\%2029MAIO2014. pdf $>$. Accessed June 10, 2014.

ABCSEM. 2009. Pesquisa de Mercado. Available at $<$ http://www.abcsem.com.br/dados-dosetor $>$ Accessed June 10, 2014.

ABERC. 2019. Mercado real. Available at $<$ http://www.aberc.com.br/mercadoreal. asp?IDMenu=21>. Accessed October 31, 2019.

ALMEIDA, D. 2006. Manual de culturas hortícolas. Lisboa: Presença, $1^{\mathrm{a}}$ ed. 343p.

ANVISA. 2016. Programa de análise de resíduos de agrotóxicos em alimentos (PARA). Relatório das análises de amostras monitoradas no período de 2013 a 2015. Available at $<$ http://portal.anvisa.gov.br/programa-deanalise-de-registro-de-agrotoxicos-para $>$. Accessed September 18, 2018.

BEZERRA， IN; MOREIRA， TMV; CAVALCANTE, JB; SOUZA, AM; SICHIERI, R. 2017. Food consumed outside the home in Brazil according to places of purchase. Revista de Saúde Pública 51: 15. Available at $<$ http://www.scielo.br/ scielo.php?script $=$ sci_arttext\&pid $=\mathrm{S} 0034$ $89102017000100214 \& \operatorname{lng}=\mathrm{en}>$. Accessed October 21, 2019.

BRASIL. 2017. CSFI - Culturas com Suporte Fitossanitário Insuficiente. Available at $<\mathrm{http}$ :// www.agricultura.gov.br/assuntos/insumosagropecuarios/insumos-agricolas/agrotoxicos/ culturas-com-suporte-fitossanitarioinsuficiente-csfi $>$ Accessed October 21, 2019.

BRUNELLI, KR; GIORIA, R; KOBORI, RF. 2011. Impacto potencial das mudanças climáticas sobre as doenças das brássicas no Brasil. In: GHINI, R; HAMADA, E; BETTIOL, W (eds). Impactos das mudanças climáticas sobre doenças de importantes culturas no Brasil. Jaguariúna: Embrapa Meio Ambiente, p.145-160.

CNA. 2017. Mapeamento e quantificação da cadeia produtiva das hortaliças. $1^{\mathrm{a}}$. ed. Brasília: CNA. 79p.

DIXON, GR. 2006. Vegetable brassicas and related crucifers. Crop Production Science in Horticulture Series 14. Wallingford: CABI, 416p.

EMATER-MG. 2019. Sistema de Informações ao Cidadão (SIC). Available at $<\mathrm{http}: / / \mathrm{www}$. emater.mg.gov.br/portal.cgi?flagweb $=$ site tpl_sic\&id=9277>. Accessed September 18, 2019.

FAST PLANTS. 2019. Origin. Available at $<$ https://fastplants.org/origin/>. Accessed October 31, 2019.

FILGUEIRA, FAR. 2008. Novo manual de olericultura: agrotecnologia moderna na produção e comercialização de hortaliças. $3^{\text {a }}$ ed. rev. ampl. Viçosa: UFV. 421p.

IBGE. 2006. Censo agropecuário. Available at $<$ http://www.ibge.gov.br/home/estatistica/ economia/agropecuaria/censoagro/default. shtm>. Accessed July 10, 2015.

IBGE. 2009. Pesquisa de orçamentos familiares - 2008/2009. Available at <http://www. ibge.gov.br/home/estatistica/populacao/ condicaodevida/pof/2008 2009 analise consumo/default.shtm $>$. Accessed July 10, 2015.

IDRESS, N; TABASSUM, B; ROBEENA, S; HUSSAIN, M. 2019. Natural compound from genus brassica and their therapeutic activities. In: SAYEED, M; MALLAPPA, KS; SINNIAH, UR. Natural bio-active compounds. p.477-491.

IEA. Estatísticas da produção paulista. 2019. Available at <http://ciagri.iea.sp.gov.br/ nia1/subjetiva.aspx?cod_sis $=1 \&$ idioma $=1>$. Accessed September 18, 2019.

INSTITUTO NACIONAL DE PESQUISAS DA AMAZÔNIA - INPA. 2014. Pesquisas com hortaliças convencionais e não convencionais buscam aumento da produção de alimentos para Amazônia. Available at $<$ https:// www.inpa.gov.br/noticias/noticia_sgno2. php? codigo $=3116>$. Accessed March 05, 2015.

INSTITUTO DE TECNOLOGIA DE ALIMENTOS - ITAL. 2010. Brasil food trends 2020. São Paulo: ITAL/FIESP, 173p. Available at $<\mathrm{http}: / /$ www.brasilfoodtrends. com.br/Brasil Food Trends/index.html>. Accessed November 18, 2015.

LANA, MM. 2010. Diagnóstico do manuseio pós-colheita de couve-flor e repolho em uma cooperativa de produtores de hortaliças de Planaltina-DF. Brasília, DF: Embrapa Hortaliças, 44p. (Embrapa Hortaliças. Documentos, 131). Available at http:// ainfo.cnptia.embrapa.br/digital/bitstream/ item/102930/1/doc-131.pdf $>$. Accessed April 24, 2017.

MELO, RAC; VENDRAME, LPC; MADEIRA, NR; BLIND, AD; VILELA, NJ. 2017. Caracterização e diagnóstico de cadeia produtiva de brássicas nas principais regiões produtoras brasileiras. Brasília: Embrapa
Hortaliças, 100p. (Embrapa Hortaliças. Documentos, 157).

MENDES, RT. 2016. Adubação borácica na cultura do brócolis. Ipameri: UEG. 67p. (M.Sc. thesis).

PAIXÃO POR BRÓCOLIS BY SAKATA. 2017. Dados de mercado e consumo. Available at $<$ http://paixaoporbrocolis.com.br/dados-demercado-e-consumo/>. Accessed January 31, 2018.

PIRES, JC. Phylogenomics of the Brassicales, Brassicaceae and Tribe Brassiceae. Available at <http://www.brassica.info/info/brass2014/ S1-1 Phylogenomics\%20of\%20the $\% 20$ Brassicales\%20Brassicaceae\%20and $\% 20$ Tribe $\% 20$ Brassiceae.pdf $>$. Accessed January 1, 2018.

RAMOS, RM; SILVA, R; DUMBRA, GR. 2013. $\mathrm{O}$ aquecido mercado dos vegetais congelados. Revista Hortifruti Brasil. 11: 122. Available at <http://www.hfbrasil.org.br/br/revista/ acessar/o-aquecido-mercado-dos-vegetaiscongelados.aspx $>$ Accessed September 18, 2015.

RIBEIRO, MTF; MEZZOMO, CPLA. 2004. A dinâmica dos arranjos institucionais do sistema agroindustrial: um estudo de caso. Economia e Gestão 4: 104-127.

SABIO, RP; VENTURA, MB; CAMPOLI, SS. 2013. Mini e "baby" frutas e hortaliças. Revista Hortifruti Brasil. 11: 120. Available at $<\mathrm{http}$ ://www.hfbrasil.org.br/br/revista/ acessar/o-mercado-de-mini-e-baby-hf-egigante.aspx $>$ Accessed September 18, 2015.

SEAB/DERAL. 2019. Olericultura - Análise da Conjuntura Agropecuária. Curitiba: Secretaria de Agricultura e Abastecimento do Paraná. Available at $<\mathrm{http} / / / \mathrm{www}$.agricultura.pr.gov. $\mathrm{br} / \mathrm{sites} / \mathrm{default} /$ arquivos_restritos/files/ documento/2019-09/olericultura 2019 v1.pdf $>$. Accessed October 31, 2019.

SEABRA JUNIOR, S; NEVES, JF; DIAS, L; SILVA, LB; NODARI, I. 2014. Produção de cultivares de brócolis de inflorescência única em condições de altas temperaturas. Horticultura Brasileira 32: 497-503.

SILVA, GS. 2012. Adubação fosfatada e potássica para repolho cultivado em Latossolo com teor alto dos nutrientes. Jaboticabal: UNESP. 36p. (Ph.D. thesis).

SILVA, ALP. 2013. Adubação fosfatada e potássica para brócolis e couve-flor em Latossolo com alto teor desses nutrientes. Jaboticabal: UNESP. 33p. (Ph.D. thesis).

SILVA, LFL; MALUF, WR; GONCPALVES, WM; RESENDE, LV; CARVALHO, RCC; SARMIENTO, CM. 2014. Variação estacional da oferta e preços de couve-flor em Minas Gerais. Revista Ceres 61: 323-331.

SOUZA, RJ. 1983. Origem e botânica de algumas brássicas. Informe Agropecuário 9: 10-12.

THE ARABIDOPSIS GENOME INIATIVE. 2000. Analysis of the genome sequence of the flowering plant Arabidopsis thaliana. Nature 408: 796-815.

YIN, RK. 2010. Case study research: design and methods. London: Sage, 264p. 